\title{
LITERATURA INFANTIL: ENTRE A INFÂNCIA, A PEDAGOGIA E A ARTE
}

\author{
Lucila Bonina Teixeira Simóes
}

\section{RESUMO}

$\mathrm{O}$ artigo tem por objetivo discutir dois conceitos fundamentais para a teoria e a crítica da literatura infantil: a concepção de criança sobre a qual se constroem as obras infantis e a função social atribuída à literatura infantil. O texto analisa como importantes teóricos da literatura infantil brasileiros trataram da questão e como as diferentes concepçóes de infância determinaram o percurso da literatura infantil no país.

PALAVRAS-CHAVE: Literatura Infantil; Teoria; Infância.

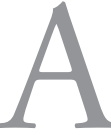

literatura infantil, em termos de teoria e crítica literárias, ainda é, e talvez continue a ser sempre, um campo aberto de definiçóes e desafios teóricos. Todas essas definições e desafios, no entanto, têm em comum o fato de serem interpelados, no princípio de qualquer elaboraçáo, a se confrontar com a noção que marca a especificidade desse gênero literário particular: o adjetivo "infantil".

O que define e distingue a literatura infantil é, justamente, seu leitor implícito, ou melhor, o que marca sua especificidade é o público a que se destina, pois é a única manifestação literária que a priori, do ponto de vista da criação literária, tem um público bem determinado. $\mathrm{E}$ isso não é um mero detalhe, ao menos para a maioria dos autores, pesquisadores e críticos, mas é um elemento fundamental e de certa forma condicionante no processo criativo. Conscientemente ou não, cada artista que se propóe a escrever um livro, o qual ele mesmo define como literatura infantil, o faz a partir de determinada idealização da 
infância, ou talvez seja mais correto afirmar, determinada concepção de infância. Sendo assim, é pertinente que qualquer problematização da produção literária para crianças, parta exatamente da problematização das diferentes concepçóes de infância que influenciam, determinam ou condicionam essa produção.

Quando alguém escreve literatura "não infantil" a imagem de seu possível leitor é menos determinante para o processo criativo. Este é um leitor tão difuso que não chega a interferir ou determinar a produção literária. Em outras palavras, ao escrever para adultos, é natural que o compromisso maior da obra seja com seu próprio ideário de valores estéticos, políticos, culturais etc. A obra permanece fiel antes de tudo a si mesma, ou a seu autor, a seu projeto artístico, ou ao modelo estético a que se vincula etc.

Quando se escreve para crianças, ao contrário, o artista é imediatamente interpelado pela função, ou papel, que sua obra vai ter diante de um leitor preferencial - a criança - que carrega uma representação social marcada pela necessidade de educação e formação. Querendo ou não, toda obra destinada a crianças precisa se submeter ao fato de que será inserida, ou será recebida, num processo de educação e instrução, seja na escola, seja na família. A diferença será marcada exatamente por qual tipo de formação será essa e para qual contexto de infância. Além disso, pela condição social de submissão e dependência de seu leitor em potencial o autor depara-se com outro leitor potencial, o adulto (pais, família ou professores) que faz a mediação entre o livro e a criança, já que mesmo tendo a criança liberdade de escolha, é o adulto quem determina o acesso ou não da criança ao livro desejado. É claro que à medida que a criança vai crescendo essa dependência vai se tornando relativa, mas o fato importante é que esse duplo interlocutor - criança e adulto - determinam para o autor certos aspectos, características e especificidades da literatura infantil já que sua própria concepção de infância, seu projeto estético endereçado à criança precisa, obrigatoriamente, dialogar com toda a construção ideológica e social sobre a infância na cultura em que se realiza.

\section{Sobre infância e literatura}

Um ponto de partida para a investigação sobre as concepções de infância vigentes na literatura infantil contemporânea é a constatação da visão adul- 
tocêntrica dessas concepçóes. É preciso admitir que a perspectiva do adulto ao olhar a infância guardará sempre diferença e distância da perspectiva da própria criança e sempre surgirá carregada de idealizaçôes. O autor do livro infantil não pode desvencilhar-se de sua condição de adulto por mais que tente assumir a perspectiva do seu leitor no momento da criação do texto. A natural condição de dependência infantil (física, psicológica, material, afetiva, etc.) torna desafiadora para o adulto a construção de uma relação igualitária, imparcial com a criança, sucumbindo o adulto, invariavelmente, à manipulação e ao autoritarismo diante da real necessidade de formação e aprendizagem do período infantil que se estabelece, também, quando um adulto se relaciona artisticamente com uma criança.

As representaçóes que os livros infantis procedem

Deixam transparecer o modo como o adulto quer que a criança veja o mundo. Em outras palavras, não se trata necessariamente de um espelhamento literal de uma dada realidade, pois, como a ficção para crianças pode dispor com maior liberdade da imaginação e dos recursos da narrativa fantástica, ela extravasa as fronteiras do realismo. E essa propriedade, levada às últimas consequências, permite a exposição de um mundo idealizado e melhor, embora a superioridade desenhada nem sempre seja renovadora ou emancipatória ${ }^{1}$.

Buscando definir o que é a literatura infantil, num estudo bastante divulgado pelo Programa Nacional de Biblioteca Escolar do Professor, José Nicolau Gregorin Filho $(2009)^{2}$ afirma que uma literatura infantil existe apenas no nível da manifestação textual. A literatura infantil nada mais é do que uma vestimenta, uma roupa infantil que os enunciadores adultos colocam na literatura para que possa ser lida e aceita como infantil pelos adultos-mediadores e pela própria criança, que, por sua vez, acaba assumindo a idealização da infância e a dicotomia mundo adulto X mundo infantil que a sociedade apresenta

1 LAJOLO, Marisa; ZILBERMAN, Regina. Literatura infantil brasileira: história e histórias. São Paulo: Ática, 1988, p. 19

2 GREGORIN FILHO, José Nicolau. Literatura infantil: múltiplas linguagens na formação de leitores. Sáo Paulo: Melhoramentos, 2010, p. 18 
a ela em seu processo educativo. Tal vestimenta tem sido construída desde que a pedagogia propôs que se publicassem textos adequados a um mundo da criança, construído histórica e ideologicamente. A mesma seria composta de uma espécie de cardápio de elementos de subcomponentes textuais identificados como infantis:

A existência desse relacionamento intertextual - o diálogo entre textos - cria a possibilidade de entender a literatura infantil como sendo aquela que contém em sua manifestação textual espaços, personagens e tempos constantes de outros textos, não somente no que se refere à pararrealidade conseguida com a releitura do mundo, mas também à crença de que existe um universo infantil, tendo como sujeitos enunciadores indivíduos apropriados de um "saber adulto". ${ }^{3}$

Segundo o autor, as crianças continuam lendo as mesmas coisas que os adultos, como acontecia antes do surgimento da pedagogia e da criação do universo infantil, só que agora os temas surgem nessa roupa confeccionada ao longo da história. A roupa infantil da literatura tende a mascarar os valores criados pela sociedade: "Tem-se, então, a manutenção do pensamento dominante na sociedade sendo feita por meio de um mecanismo que disfarça o caráter doutrinário encontrado em discursos como o religioso e o político, pelo mito que se construiu de literatura infantil." " $\mathrm{O}$ ponto que mais interessa nesse postulado de Gregorin Filho é o desmascaramento que proporciona sobre as implicações - redutoras ou potencializadoras - da construção ideológica da infância que determinam a produção da literatura infantil.

Confronta-se assim, novamente, a realidade de que a produção literária para crianças se pauta pelo conceito construído histórica e culturalmente pela sociedade, tanto de infância como de qual a função da literatura "vestida" como infantil.

O conceito de criança nem sempre foi o mesmo. Aliás, Regina Zilberman afirma que possa ser a literatura infantil um "gênero incompreensível

3 GREGORIN FILHO, op. cit., p. 18-19

4 Idem, op. cit., p. 21 
sem a presença de seu destinatário, a literatura infantil não pôde surgir antes da infância." 5 Sendo assim, apenas quando a criança passa a ser percebida como um ser diferente do adulto - e não apenas uma "miniatura" dele, - com necessidades e características próprias, é que começam a surgir produtos culturais endereçados particularmente a elas com a função de prepará-las para a vida. Antes disso, a criança acompanhava a vida social do adulto, participando também de sua literatura. Apenas em meio à Idade Moderna, com a ascensão da burguesia e o estabelecimento de uma nova noção de família a partir de um núcleo unicelular, preocupado em manter sua privacidade e propriedade, estimulando o afeto entre seus membros, é que surge uma definição do que seria a infância e qual a função do adulto em relação a essa infância.

Antes da constituição deste modelo familiar burguês, inexistia uma consideração especial para com a infância. Esta faixa etária não era percebida como um tempo diferente, nem o mundo da criança como um espaço separado. Pequenos e grandes compartilhavam dos mesmos eventos, porém nenhum laço amoroso especial os aproximava. A nova valorização da infância gerou maior união familiar, mas igualmente os meios de controle do desenvolvimento intelectual da criança e a manipulação de suas emoçôes. Literatura infantil e escola, inventada a primeira e reformada a segunda, são convocadas para cumprir essa missão. ${ }^{6}$

A constituição e manutenção desse estereótipo da família burguesa, com uma divisão bem definida de funçóes, na qual cabe ao pai o provimento econômico e à mãe a administração da vida doméstica privada, ambos dedicados ao atendimento integral dos filhos, torna-se a finalidade existencial do indivíduo. A criança, portanto, passa a receber um prestígio social antes inexistente. Porém, contraditoriamente, tal prestígio reforça a condição de dependência e submissão da criança.

5 ZILBERMAN, Regina. A literatura infantil na escola. 2a ed. São Paulo: Global, 1982, p. 39

6 ZILBERMAN, op.cit., p. 15. 
A criança passa a deter um novo papel na sociedade, motivando o aparecimento de objetos industrializados (o brinquedo) e culturais (o livro) ou novos ramos da ciência (a psicologia infantil, a pedagogia ou a pediatria) de que ela é destinatária. Todavia, a função que lhe cabe desempenhar é apenas de natureza simbólica, pois se trata antes de assumir uma imagem perante a sociedade, a de alvo da atençáo e interesse dos adultos, que de exercer uma atividade econômica ou comunitariamente produtiva, da qual adviesse alguma importância política e reivindicatória. Como decorrência, se a faixa etária equivalente à infância e o indivíduo que a atravessa recebem uma série de atributos que o promovem coletivamente, são esses mesmos fatores que o qualificam de modo negativo, pois ressaltam, em primeiro lugar, virtudes como a fragilidade, a desproteção e a dependência. ${ }^{7}$

É nesse contexto que se desenvolve uma nova noção de escola, a serviço da nova ordem social que se estabelecia: "Tendo sido facultativa, e mesmo dispensável até o século XVIII, a escolarização converte-se aos poucos na atividade compulsória das crianças, bem como a frequência às salas de aula, seu destino natural". ${ }^{8}$ Uma vez que se concebe a criança como um ser frágil e despreparado, é fundamental que escola e família se dediquem a prepará-la para o enfretamento maduro do mundo.

A noção, ou melhor, noçóes, que temos de criança hoje em dia são vinculadas a essa idealização burguesa de infância, principalmente no que diz respeito à concepção da criança como um ser diferenciado por sua condição de ser em desenvolvimento, com mais necessidades que possibilidades de ação social e por sua imaturidade intelectual e afetiva que demanda, do adulto, cuidados especiais para sua proteção e desenvolvimento adequados. A partir desse momento histórico, a infância corporifica dois sonhos do adulto: em primeiro lugar porque encarna o ideal do "bom selvagem", cuja naturalidade é preciso conservar enquanto o ser atravessa o período infantil. Em segundo

7 LAJOLO; ZILBERMAN, op.cit., p. 17

8 Idem, p. 18 
lugar, porque sobre a criança o adulto pode expandir seu desejo de superioridade mantendo sobre ela um poder inquestionável.

São as instituiçốes encarregadas do atendimento aos jovens que projetam e propagam esta imagem da infância: a literatura infantil passou a ocupar ao lado da escola e da família um papel fundamental na formação dos indivíduos. Mesmo postulando o ideal de que a literatura infantil deva ser, antes de tudo, arte, e que em nada difere da outra literatura (sem adjetivos), a sociedade espera que o papel de formaçáo, seja do gosto, seja da capacidade crítica e criativa até a aquisição de conhecimentos assuma, na produção literária para crianças, uma marca fundamental.

Abordando a questão do conceito de infância para, a partir dela, delimitar o conceito de literatura infantil, Peter Hunt (2010) aponta como essencial ter em conta a multiplicidade de concepçóes de infância ante a análise de obras dedicadas a crianças.

Em suma, a infância não é hoje (se é que alguma vez foi) um conceito estável. Por conseguinte, não se pode esperar que a literatura definida por ela seja estável[...], pois os conceitos de infância vão alterar radicalmente o texto e são muito mais instáveis que os conceitos referentes aos adultos [...] a cultura do livro toma decisôes sobre a infância, e em diversos sentidos a cria ou a destrói. ${ }^{9}$

Philippe Ariès $(1981)^{10}$, no estudo sobre a história da infância que se tornou referência para quem se debruça sobre o tema, afirma que a infância foi uma invençâo da modernidade, constituindo-se numa categoria social construída recentemente na história da humanidade. Para ele a noção de infância como um período particular da vida humana - que ele chamou de sentimento de infância - não foi um processo natural, mas o resultado de um longo processo histórico. Até o final da Idade Média a criança só recebia uma atenção diferenciada até um desmame tardio, por volta dos sete anos de idade. A partir

9 HUNT, Peter. Crítica, teoria e literatura infantil. Trad. Cid Knipel. Ed. Rev. São Paulo: Cosac Naify, 2010, p. 94-95

10 ARIÈS, Philippe. História social da criança e da família. 2.ed. Rio de Janeiro: LTC, 1981. passim. 
daí, quando podia dispensar os cuidados da mãe, ela participava da vida dos adultos em todas as suas manifestaçóes: no trabalho, nas execuçóes, nas festas, nas guerras etc. Sendo assim, participava também de todas as manifestaçôes culturais comuns a todos: os cantos, os jogos e as narraçóes de histórias etc. Porém, mesmo participando de forma igualitária da vida dos adultos, a criança era excluída das decisóes.

Ariés demonstra que os séculos XVI e XVII esboçaram uma noção de infância centrada na inocência, na pureza e na fragilidade infantil. $\mathrm{O}$ século XVIII inaugurou a construção da infância moderna com a noção de liberdade, autonomia e independência que marcariam essa etapa da vida que deveria ser logo ultrapassada para que o indivíduo se tornasse rapidamente produtivo e colaborasse com a comunidade. Por outro lado, a sociedade projeta na criança a imagem da pureza, do homem ideal náo corrompido, do período por excelência da vida humana, o qual o adulto irremediavelmente perdeu. Sendo assim, é necessário proteger sua inocência, reafirmando sua fragilidade.

Instaura-se assim uma ambiguidade no conceito de infância que, a despeito das mudanças sociais através do tempo, sempre a acompanhará e, consequentemente, a todas as açóes ou produtos culturais destinados à criança. Zilberman afirma a esse respeito que essa concepção contraditória de infância foi uma elaboração do adulto diante do sentimento de perder ou abandonar o período infantil a partir do caráter utópico e idealista atribuído a este.

Enquanto isto, como a criança verdadeira era ilhada, porque tornada alheia aos meios de produção, e comprimida pelos mais velhos, que assim asseguravam seu prestígio e dominação, foi elaborada uma série de atributos, os quais revestiram a qualificação dos pequenos e reproduziram ideologicamente sua diminuição social: a menoridade, a fragilidade física e moral, a imaturidade intelectual e afetiva. É o que leva todo menino, que vivencia diariamente a inferioridade, a querer suplantar essa fase e todo adulto a almejar sua recuperação, após fazê-la passar pelo filtro da idealização. ${ }^{11}$

11 ZILBERMAN, Regina. op. cit., p. 18-19. 
A problematização do conceito de infância na contemporaneidade exige que se abra espaço para a multiplicidade e a parcialidade das representaçóes desse período de vida. Se o conhecimento não é único, segundo o projeto da pós-modernidade, e sim múltiplo, variável, fragmentado e mutável, inscrito nas relaçóes de poder, é preciso admitir que qualquer conceituação que se pretenda para a noção de infância não poderá aparecer mais como uma verdade fechada e absoluta. $\mathrm{Na}$ verdade, não há uma infância, há várias. Apenas uma breve observação da realidade social brasileira já apresenta, ao menos, dois tipos de infância existindo no mesmo tempo, na mesma sociedade, reunida na escola (que é o principal local de circulação da literatura infantil na sociedade brasileira), num sistema educacional que se pretende universal, no mesmo espaço de convivência:

Neste início de século XXI, pode-se encontrar uma grande variedade de "infâncias" coexistindo nas mais diversas sociedades, desde aquelas que ainda não conhecem as transformaçóes sofridas pela escola e seguem trabalhando como adultos, até aquelas que vivem imersas num mundo puramente tecnológico, também afastadas das atividades lúdicas tão necessárias ao desenvolvimento do ser humano [...] tem-se, desse modo, diferentes crianças em múltiplas realidades numa mesma sociedade e, assim, a escola se torna um espaço de convergência de todas essas realidades. ${ }^{12}$

Não existe algo como criança ou infância enquanto realidade única e universal a ser descoberta. $\mathrm{Na}$ verdade o que existem são muitas crianças e muitas infâncias, cada uma delas construída a partir de determinados olhares, influenciados por interesses e ideologias que estejam vigorando no tecido social em determinado momento histórico. Nessa perspectiva, a infância deve ser compreendida como um modo particular de se pensar a criança, e não um estado universal, vivida por todos do mesmo modo.

Apesar de a criança ser um conceito infinitamente variado,

${ }^{12}$ GREGORIN FILHO, op.cit., p. 42 
Ao falar sobre livros para crianças, algumas generalizaçóes devem ser feitas, ou a linguagem se torna incontrolável, porém não se pode esquecer o fato de que o conceito de criança é um problema sempre presente para a crítica da literatura infantil. ${ }^{13}$

Três pressupostos, conforme Hunt, compóem a idealização de infância que será determinante na literatura infantil: a infância como um estado que pode e deve ser manipulado pelo adulto para atingir seu pleno desenvolvimento; a infância como um estado puro, inocente, que precisa ser preservado; a infância como uma série de estados de desenvolvimento. Diferentes combinaçôes desses pressupostos geram diversas formas de conceber a criança para a qual se produz literatura.

Buscando fazer generalizaçóes, como sugere Hunt, sobre concepçóes de infância que determinam a produção literária infantil a fim de compreendê-la, e investigando esse problema em autores e obras que se tornaram referência obrigatória nos estudos sobre literatura infantil no Brasil, é possível estabelecer duas concepçôes bem demarcadas e opostas enformando a produção literária para crianças. A primeira concepção de infância, nomeada conservadora ${ }^{14}$, decorre da cristalização da noção burguesa de infância, ou seja, a criança é um ser frágil e dependente, portanto, passível de proteção e cuidados; a criança conhece pouco do mundo, portanto não é capaz de refletir sobre ele ou discuti-lo, sendo fundamental que o adulto a guie, paulatinamente num processo de aprendizagem definido pelo adulto, para que se torne um ser humano completamente formado. Assim, as características peculiares da criança, como o desenvolvimento físico incompleto, a abertura para a fantasia e a capacidade/ necessidade de aprender por meio da brincadeira são usados como meios de incutir na criança os valores pré-determinados pelo adulto. Nelly Novaes Co-

13 HUNT, op.cit., p. 291

14 Essa concepçáo tem sido nomeada de diferentes formas por alguns teóricos. Zilberman chama essa concepção mais tradicional e cristalizada de infância de "conservadora" em oposição a uma concepção que seria "emancipadora". Coelho a chama de "tradicional" em oposição ao que ela chama de "novo valor" na literatura infantil. Cunha, ao se referir a essa forma de conceber a criança a define como uma concepção "pedagógica”. Optamos pelos termos usados por Zilberman - conservador- emancipador - para definir as concepçóes de infância por remeterem imediatamente à função social esperada da literatura infantil ao se conceber a infância desse modo. 
elho assim enuncia essa concepção conservadora de infância e sua relação com a literatura infantil: "A criança é vista como um 'adulto em miniatura', cujo período de imaturidade (a infância) deve ser encurtado o mais rapidamente possível. Daí a educação rigidamente disciplinadora e punitiva; e a literatura exemplar que procurava levar o pequeno leitor a assumir, precocemente, atitudes consideradas 'adultas"”. ${ }^{15}$

A segunda concepção, chamada emancipadora, não concebe a criança como um "vir a ser", mas como um ser que "já é", mesmo que vivenciando um período particular de desenvolvimento. A fragilidade física não se volta contra a criança, mas é motivo de discussão sobre suas possibilidades e seu próprio desenvolvimento; a falta de conhecimento e experiências acerca do mundo não é justificativa para a segregação de temas e imposição de valores, mas motivos para o exercício e o desenvolvimento da autonomia e da capacidade de crítica. A abertura à fantasia e ao lúdico é o espaço do diálogo, da identificação entre a criança e o mundo, e fonte de prazer e beleza. "A criança é vista como um ser-em-formação, cujo potencial deve desenvolver-se em liberdade, mas orientado no sentido de alcançar total plenitude em sua realização." 16

Os limites entre uma concepção e outra não são tão demarcados na realização concreta dos textos como na teoria, mas é possível verificar a incidência maior ou menor dessas concepçóes na criação literária, principalmente no que diz respeito à função social atribuída (ou praticada) pelo autor à sua literatura infantil que vai determinar o percurso da criaçấo literária da obra.

Discutindo o estatuto da literatura infantil, Regina Zilberman (1987) ${ }^{17}$ salienta esse caráter dual da literatura infantil em relação a seu público leitor: por seu vínculo histórico com a pedagogia - visto que literatura infantil e escola provêm de uma gênese comum, qual seja: estar a serviço das necessidades de manipulação/formação da infância da família burguesa - foi-lhe sempre imputado um estatuto menor, quando não inexistente, perante a

15 COELHO, Nelly Novaes. Literatura infantil: história, teoria, análise. São Paulo: Moderna, 2000, p. 7

16 Idem

17 ZILBERMAN, Regina. O estatuto da literatura infantil. In MAGALHÁES, Lígia Cadermatori; ZILBERMAN, Regina. Literatura infantil: emancipação e autoritarismo. São Paulo: Ática, 1987, passim. 
arte literária: "Como se a menoridade de seu público a contagiasse, a literatura infantil costuma ser encarada como produção cultural inferior". ${ }^{18}$ Por outro lado, ela supera a aparente inferioridade de seu estado exatamente por uma sua peculiaridade artística; ou seja, pelo fato de não conhecer fronteiras estéticas, já que não é determinada nem pela forma (verso ou prosa, novela ou conto), nem por um tema específico, passeando livremente entre o realismo e o maravilhoso e admitindo modalidades próprias, como o conto de fadas, a fábula e outras histórias com animais. Além disso, incorpora ao texto a ilustração tornando-se uma manifestação literária única exatamente por carregar esse diálogo intersemiótico em sua constituiçãa. Segundo Zilberman,

Em vista disto, explicita-se a duplicidade congênita à natureza da literatura infantil: de um lado percebida sob a ótica do adulto, desvela-se sua participação no processo de dominação do jovem, assumindo um caráter pedagógico, por transmitir normas e envolver-se com sua formação moral. De outro, quando se compromete com o interesse da criança, transforma-se num meio de acesso ao real, na medida em que lhe facilita a ordenação de experiências existenciais, através do conhecimento de histórias, e a expansão de seu domínio linguístico. ${ }^{19}$

Nelly Novaes Coelho discute essa duplicidade de tendências da literatura infantil quando afirma que um dos primeiros problemas a suscitar polêmica no âmbito da literatura infantil quanto à sua forma ideal foi exatamente a definição de sua natureza específica: a literatura infantil pertenceria à arte literária ou à área pedagógica? Mas para a autora, essas duas atitudes conflitantes não são gratuitas, resultam da indissolubilidade que existe entre a intenção artística e a intenção educativa, incorporadas nas próprias raízes da literatura infantil. Conseguir um equilíbrio entre as duas tendências - literária e pedagógica - seria o ideal da literatura infantil, visto que elas só se excluem quando se radicalizam:

18 LAJOLO; ZILBERMAN, op.cit., p. 11

19 ZILBERMAN, 1982, op. cit, p. 14 
Felizmente para equilibrar a balança, há já uma produção infantil e juvenil de muito bom nível, que conseguiu, com rara felicidade, equacionar os dois termos do problema: literatura para divertir, dar prazer, emocionar... e que, ao mesmo tempo, ensina novos modos de ver o mundo, de viver, pensar, reagir, criar... E principalmente se mostra que é pela invenção da linguagem que essa intencionalidade básica é atingida. ${ }^{20}$

Maria Antonieta Antunes Cunha (1988) também confronta a dualidade gerada pelas diferentes concepçóes de infância que podem condicionar a literatura infantil a um caráter puramente pedagógico. A autora teoriza sobre a literatura infantil buscando resposta a esta indagação: seria a literatura infantil uma traição ao leitor-criança, na medida em que seu discurso reflete um encaminhamento da infância, que não tem voz nesse discurso e não pode posicionar-se? Segundo ela a pergunta só seria pertinente se considerar-se que as obras com claro comprometimento pedagógico são literatura. A autora observa que em obras desse tipo há uma redução da criança à concepção de que a criança é, simplesmente, um ser educável, subestimando-se toda a complexidade do que seja a infância.

Muitas obras feitas para crianças e ditas de literatura infantil não se desprendem de uma peculiaridade do discurso pedagógico: a redução da criança, notadamente pela facilitação artística (puerilidade) e pelo tom moralizador. Nesse caso, temos uma pretensa literatura infantil, exatamente como, dentro da produção artística para adultos, existem lamentáveis equívocos: há maus romances, maus poemas, maus contos. E ninguém invalida a literatura por isso. ${ }^{21}$

Por outro lado, Cunha mostra que, quando o adulto percebe a criança com um ser complexo e completo, embora ainda em desenvolvimento, ou

20 COELHO, op. cit., p. 27

21 CUNHA, Maria Antonieta Antunes. Literatura infantil: teoria e prática. São Paulo: Ática, 1988 , p. 22 
seja, atravessando um período em que perspectivas e expectativas são maiores que as possibilidades de realização, a literatura criada por ele para seu leitor-criança não se configura uma traição porque acredita e aposta na liberdade/ capacidade da criança de estabelecer suas relaçóes com o mundo também através da linguagem literária.

\begin{abstract}
A literatura infantil enquanto manifestação artística não é traição: apesar de ser sempre o adulto a falar à criança, se ele for realmente artista, seu discurso abrirá horizontes, proporá reflexão e criação, estabelecerá a divergência, e não a convergência. E suas verdadeiras possibilidades educativas estão aí. ${ }^{22}$
\end{abstract}

Maria Antonieta Cunha apresenta, na problematização da literatura infantil, outro ator, também este adulto, que se coloca como o quarto elemento fundamental na constituição da cena literária infantil: o mediador do encontro entre o texto, enunciado por um autor adulto, e a criança-leitora. Essa mediação é operada pelos pais e professores responsáveis pela educação da criança. O grande dilema da literatura infantil, segundo Cunha, está no erro de perspectiva do adulto ao lidar com a obra literária. Para ela é fundamental que o adulto-mediador saiba distinguir entre as duas tendências para as quais livros endereçados à infância podem pender e, por consequência, encaminhar o encontro adequado entre a criança e o livro de acordo com cada tendência, visto que ambas coexistem e são igualmente necessárias à formação completa da criança:

Infelizmente para a literatura, sua matéria-prima - a palavra - não lhe é exclusiva: ela serve tanto à informação quanto à arte. Isto não acontece com as outras artes, cuja matériaprima é imediatamente identificada com sua expressão artística: o som, para todos, liga-se à música; as cores, à pintura - e assim por diante [...] Ora, lidamos na escola ou na família com a palavra-arte como se ela fosse palavrainformação. Trabalhamos com a literatura do mesmo modo

${ }^{22}$ Idem, op.cit., p. 23 
que com a Matemática, ou a Geografia: não distinguindo objetivos diferentes, não usamos estratégias diferentes, para as duas espécies de palavra. ${ }^{23}$

Maria Antonieta Cunha distingue duas espécies de livros infantis, não considerando, para efeito de estudos, literatura infantil as obras com teor informativo, didatizante, moralizador. No entanto, essa parece uma solução simplista e uma vez que se verifica na vastíssima e crescente produção contemporânea a coexistência das duas tendências na produção que se autoidentifica indistintamente literatura infantil. Por isso, parece mais coerente, que qualquer teorização ou crítica sobre a produção literária contemporânea para crianças não deixe de fora a análise sobre a(s) concepção (óes) de infância que emergem da obra, sabendo que a eventual opçáo do escritor em relação a uma dessas atitudes básicas, não depende exclusivamente de sua decisão pessoal, mas da tendência predominante em seu contexto cultural, fazendo com que se denomine indistintamente literatura infantil, obras com diversas e até díspares tendências e características.

$\mathrm{Na}$ perspectiva de uma concepção conservadora de infância, a literatura infantil é, preponderantemente, a expressão da palavra-informaçâa ${ }^{24}$ em que a função da literatura infantil deve ser formativa e informativa, portanto atendendo à necessidade de instrução da criança, ao mesmo tempo em que atende sua necessidade pela fantasia, pela distração, pela ludicidade e pelo desenvolvimento de sua imaginação e criatividade.

$\mathrm{Na}$ perspectiva de uma concepção emancipadora da criança, a literatura infantil é, ao contrário, a expressão da palavra-arte em que a literatura infantil não é exclusivamente informação, mas pluralidade de significados, possibilitando múltiplas interpretações e possibilidades de fruição, como, ademais, é a função de toda outra obra de arte: fonte de conhecimento, reflexão e prazer estético consistindo, justamente nisso, sua função formativa e emancipadora.

23 Idem, op.cit., p. 41-42

24 Os termos" palavra-informação" e "palavra-arte" , cunhados por Maria Antonieta Cunha (1988) serão usados para designar as duas funções sociais assumidas pela literatura infantil e que estão ligadas às concepçôes conservadora e emancipadora de infância. 


\section{A noção de infância no percurso da literatura infantil no Brasil}

A literatura infantil no Brasil é uma manifestação literária muito recente, principalmente para quem considera que apenas a partir de 1895 , com a publicação de Contos da Carochinha, de Alberto Figueiredo Pimentel é que se pode falar em uma produção autenticamente nacional de livros para crianças. Muitos dos estudos - esses recentíssimos - voltados especificamente para a literatura infantil ainda se detêm exatamente em compor o percurso histórico dessa produçáo. Diferentes caminhos e formas se têm encontrado para relatar e interpretar tal percurso. Entre eles, acredita-se poder afirmar que o percurso ou evoluçáo da literatura infantil brasileira pode ser entendido como uma evolução da alternância entre as duas tendências que a tem definido historicamente: a tendência pedagógica e a literária; ou dito de outra forma, a prevalência da palavra-informação, tendência vinculada à concepçáo conservadora de infância, ou da palavra-arte, decorrente da concepçáo emancipadora da infância, como expressão do que seja a literatura infantil.

Nesse sentido, não será prioridade aqui traçar um registro histórico, com datas, autores e obras da literatura infantil no Brasil, e sim buscar compreender como as mudanças nas formas de perceber a criança influenciaram as rupturas e continuidades desse percurso.

Maria Antonieta Cunha (1988), apesar de achar prematuro traçar uma história do gênero literário no país, aponta dois momentos bem definidos no percurso histórico, determinados pela mudança de perspectiva dada a criança e pelo contexto sócio-político brasileiro:

No Brasil, como não poderia deixar de ser, a literatura infantil tem início com obras pedagógicas e sobretudo adaptadas de produçóes portuguesas, demonstrando a dependência típica das colônias.

Essa frase embrionária da literatura infantil brasileira é representada em especial por Carlos Jansen (Contos seletos das mil e uma noites, Robinson Crusoé, As viagens de Gulliver a terras desconhecidas), Figueiredo Pimentel (Contos da Carochinha), Coelho Neto e Olavo Bilac (Contos pátrios) e Tales de Andrade (Saudade). 
Com Monteiro Lobato é que tem início a verdadeira literatura infantil brasileira. Com uma obra diversificada quanto a gêneros e orientação, cria esse autor uma literatura centralizada em alguns personagens, que percorrem e unificam seu universo ficcional. ${ }^{25}$

Cunha observa que mesmo compondo obras marcadamente didáticas, Lobato escreve outras de exploração do folclore ou de pura imaginação, com ou sem aproveitamento de elementos e personagens da literatura infantil tradicional. Outra novidade introduzida por Lobato, e que demonstra uma nova forma de perceber e se relacionar artisticamente com a infância, foi a introdução do questionamento e inquietação intelectual atribuída aos personagens crianças, a preocupação com as questóes nacionais ou os grandes problemas mundiais, temáticas expressas numa língua marcada pelo aproveitamento do dialeto brasileiro, bem mais próximo das crianças. "O escritor de Taubaté estava abrindo caminho para muitos escritores de talento, que, sobretudo na última década, vêm criando uma respeitável obra endereçada à criança." 26 Apesar disso, Cunha observa que a então recente produção literária para crianças ainda se ressentia da excessiva preocupação pedagógica, fato que ainda corresponde à realidade da atual produção mesmo quando já consolidou a preocupação estética como legitimadora e condição indispensável nos livros de literatura infantil.

Gregorin Filho (2009), ratificando a elaboração já consagrada de que a história da literatura infantil brasileira divide-se em dois momentos distintos, o período fundador anterior a Lobato e o momento atual, pós lobatiano, chama a atenção para o fato de que a história da literatura infantil vincula-se, de certa forma também, à história das práticas pedagógicas que foram se impondo na educação brasileira, libertando-se gradativamente da imposição puramente pedagógica. Apesar dessa libertação, a literatura manteve uma relação muito íntima com a escola visto que, enquanto produto cultural de consumo, é na escola que a literatura infantil se realiza plenamente, já que são as bibliotecas escolares a via de acesso à literatura mais importante, quando não única, da maior parte da população infantil brasileira.

25 CUNHA, op. cit., p. 20

26 Idem 
Adota-se aqui a organização do percurso histórico, proposta pelo autor, em quatro momentos bem demarcados da história da literatura infantil no Brasil, em relação a alguns dos principais fatores histórico-sociais e às práticas pedagógicas vigentes em cada período. Eles são: a) Período dos Precursores; b) Período de Monteiro Lobato; c) Período Pós-Lobato; d) Contemporâneo.

O primeiro período que vai do Brasil-Colônia até a década de 1920, é o período dos precursores. Um período que vai da absoluta falta de preocupação com um projeto educativo formal no país até as primeiras iniciativas de organização e sistematização da instrução pública. Na educação e na prática de leitura no Brasil os paradigmas vigentes eram o nacionalismo, o intelectualismo, o tradicionalismo cultural com seus modelos de cultura a serem imitados e o moralismo religioso. Todos esses paradigmas eram nada mais que o reflexo dos padróes europeus que se encontravam e confrontavam com os valores de um país que lutava pela busca de sua identidade e procurava ser valorizado enquanto nação. Os livros destinados à infância eram basicamente traduçóes e adaptaçóes de obras europeias em que abundavam as fábulas, os contos de fada maravilhosos, as novelas de aventura e de cavalaria e livros de leitura, organizados como seletas, de circulação específica nas escolas. A criança era vista "como um indivíduo pronto para receber a educação como dádiva, como caráter divino, e amar sua pátria como berço e fonte inesgotável de benevolências." ${ }^{27}$. A literatura infantil se definia como um instrumento pedagógico pautado pela exemplaridade e pela doutrinação.

O segundo período, da década de 1920 a meados da década de 1980, é um momento fundamental para a literatura infantil, momento de ruptura operada pela produção de Monteiro Lobato. Ele inaugura uma nova literatura infantil brasileira, literatura que ainda passaria por inúmeras transformações e experimentaçóes, por uma ditadura militar e por drásticas e velozes mudanças na tecnologia e na sociedade.

Leonardo Arroyo (1968), em estudo pioneiro sobre a literatura infantil brasileira Literaura infantil brasileira: ensaio de preliminares para sua história e suas fontes, já estabelece o "gênio" de Lobato como marco fundamental da história literária brasileira.

${ }^{27}$ GREGORIN FILHO, op. cit., p. 28 
Embora estreando na literatura escolar com Narizinho arrebitado, Monteiro Lobato trazia já com seu primeiro livro as bases da verdadeira literatura infantil brasileira: o apelo à imaginação em harmonia com o complexo ecológico nacional; a movimentação dos diálogos, a utilização ampla da imaginação, o enredo, a linguagem visual e concreta, a graça na expressão toda uma soma de valores temáticos e linguísticos que renovava inteiramente o conceito de literatura infantil no Brasil, ainda preso a certos cânones pedagógicos decorrentes da enorme fase da literatura escolar, fase essa expressa, geralmente, em um português já de si divorciado do que se falava no Brasil. ${ }^{28}$

O aspecto mais inovador da proposta literária de Lobato foi que "a criança passa a ter voz, ainda que uma voz vinda da boca de uma boneca de pano, Emília. A contestação e a irreverência infantis sem barreiras começam a ter espaço e a ser lidas, e adquirem maior concretude com as ilustraçóes das personagens do Sítio do Pica-Pau Amarelo" ${ }^{29}$. Além disso, Lobato apresenta temas nunca explorados no universo literário para crianças, como a preocupação com problemas sociais, soluçóes idealistas e liberais para esses problemas e o questionamento da religião e dos valores tradicionais, para citar alguns.

Com Lobato os pequenos leitores adquirem consciência crítica e conhecimento de inúmeros problemas concretos do país e da humanidade em geral. Ele desmistifica a moral tradicional e prega a verdade individual. Instaura, portanto, a liberdade. Sem coleiras, pensando por si mesma, a criança vê, num mundo onde não há limites entre a realidade e a fantasia, que ela pode ser agente de transformação. ${ }^{30}$

28 ARROYO, Leonardo. Literatura infantil brasileira. 3.ed. revista e ampliada. São Paulo: Editora Unesp, 2011, p. 281

29 GREGORIN FILHO, op. cit., p. 28

30 SANDRONI, Laura. De Lobato a Bojunga: as reinaçóes renovadas. 2.ed. Rio de Janeiro: Nova Fronteira, 2011, p. 54 
A criança, ainda que sujeita ao processo educativo determinado ideologicamente pelo adulto, começa a ser percebida como uma realidade mais complexa, capaz de reflexão e crítica. A literatura infantil continua sendo, nesse período, um instrumento pedagógico, mas começa a expandir suas fronteiras e lança as bases para sua existência "independente" da escola, por introduzir e representar o relativismo de valores presentes na sociedade às crianças.

A obra de Lobato teve tanta importância e obteve tanto sucesso de público em sucessivas reediçóes que durante muito tempo, depois de 1920, a literatura infantil brasileira permaneceu semiestagnada, oscilando entre várias e frustradas tentativas de imitação da obra lobatiana, a permanência das fórmulas tradicionais do período anterior, agora menos aceitas pelo público e o aparecimento de autores que souberam imprimir sua originalidade e escreveram livros que se mantêm até hoje no catálogo das editoras. Autores como Menotti Del Picchia, Malba Tahan, José Lins do Rego, Viriato Correia, Érico Veríssimo, Orígenes Lessa, Lúcia Machado de Almeida, Maria José Dupré, entre outros. "Em maior ou menor grau, eles realizaram obras nas quais o imaginário e o lúdico encontraram uma linguagem adequada para expressar-se, abordando temas históricos ou de inspiração folclórica, ou ainda criando aventuras maravilhosas". ${ }^{31}$

Segundo Laura Sandroni, a partir de 1970, algumas modificaçôes começam a ser notadas com o aparecimento de novos autores e uma grande diversificaçâo da produção para atender ao crescimento do público leitor criado pela lei de reforma do ensino que obrigava a adoção de autores brasileiros nas escolas do, então, ensino de primeiro grau. Novamente a literatura infantil se vê intimamente ligada ao sistema de ensino. Se por um lado esse fato póe em risco a leitura como fronte de prazer e fruição quando o poder de decisão e escolha do professor poderia levá-lo a oferecer às crianças textos com intenção puramente didática; por outro lado propiciou o clima favorável para o aparecimento de muitos autores que, seguindo o rastro aberto por Lobato, vêm produzindo obras sem perder de vista o lúdico, o imaginário, o humor, a preocupação com a linguagem inovadora e poética levando a criança-leitora à reflexão e à crítica.

31 SANDRONI, op. cit., p. 62 
A grande revoluçâo operada por Monteiro Lobato na literatura infantil brasileira poderia ser expressa com uma imagem: a produçâo de livros para crianças até 1920 se apresentava como um adulto que carrega uma criança no colo. Além de expressar proteção e cuidado, segurar a criança no colo póe em relevo a fragilidade e a incapacidade da criança de se sustentar com os próprios pés. Além disso, no colo do adulto a criança não tem liberdade de olhar na direção que desperta sua atenção, mas está sujeita a olhar apenas a direção que o adulto aponta e essa direção é sempre marcada por uma visão idealizadora, porque simplista, para não dizer pueril, de mundo. É então que Lobato pega a criança e a póe em pé no chão a seu lado. Indo além, o adulto Lobato é que se inclina para alcançar a perspectiva da criança e, a partir daí, continuar apontando não uma, mas muitas formas de ver o mundo. Ele constata e aposta naquilo que os demais autores ainda não tinham percebido: a criança é um ser inteligente e capaz de juízos críticos. Disso é que decorre sua postura inovadora: a relação de respeito - e não de dominação - que tem com seu jovem leitor.

Diferentemente dos autores que o antecederam, adultos falando aos pequenos, Lobato prefere fazer como Dona Benta: senta-se na cadeira de pernas serradas e, desse ângulo de visão, procura enxergar o mundo pelo olhar da criança. Despe a linguagem dos adornos desnecessários (a "literatura" que é preciso extirpar com raspadeira, como diria em carta a Rangel), abdica do autoritarismo e do tom prelecional próprios do adulto que fala à criança e deixa a imaginação aflorar, com o "faz de conta" dominado a ação. ${ }^{32}$

Numa famosa carta ao editor Godofredo Rangel, referida por Arroyo (2011), o próprio Lobato explicita seu projeto de literatura infantil: "De escrever para marmanjos já me enjoei. Bichos sem graça. Mas para as crianças, um livro é todo um mundo [...] ainda acabo fazendo livros onde as nossas crianças possam morar”. Essa afirmação além de revelar certa desilusão com a realidade adulta que o cercava, deixa entrever a idealização da infância que permeia a

32 SILVA, Vera Maria Tieztmann. Literatura infantil brasileira: um guia para professores e promotores de leitura. 2. Ed. Goiânia: Cânone Editorial, 2009, p. 111 
obra de Lobato quando elege a infância como sua principal interlocutora: a criança é vista como a única possibilidade de modificação do mundo. Ele escreve para uma geração que pode e deve mudar o futuro e a literatura infantil deve influir na formação de um Brasil melhor através das crianças. Apesar de representar uma mudança significativa em direção à superação da concepção conservadora de infância, a visão de Lobato ainda é problemática, pois representa não a criança concreta, do presente, mas idealiza uma criança que é a esperança de mudança no futuro, subestimando todos os outros fatores que determinam e influenciam a transformação dessa criança em adulto e que podem frustrar a excessiva "esperança” e responsabilidade colocada sob os ombros das crianças. Além disso, o projeto de Lobato continua justificando o tom didatizante e a prevalência da palavra-informação em muitas de suas obras.

Mesmo assim, foi justamente da geração dos que cresceram lendo Lobato que surgiram os maiores e melhores escritores da literatura infantil atual. Escritores que, como Lobato, respeitam o leitor-criança, apostam na sua inteligência e os estimulam a pensar, a discutir, a exercitar um olhar crítico em relação ao mundo.

Podemos apontar diversas características temáticas e formais que têm suas raízes no Sítio do Picapau Amarelo e que constituem o legado de Lobato à literatura infantil brasileira. $\mathrm{Na}$ produção contemporânea, vemos Lobato emergir da escritura dos mais significativos autores. Ele se faz presente na linguagem coloquial de Lygia Bojunga, no olhar questionador dos personagens de Ana Maria Machado, no humor de Ruth Rocha, só para citar os canônicos. Como o Sítio do Picapau Amarelo, são mundos "sem coleiras" que os bons autores de hoje nos revelam em suas histórias. ${ }^{33}$

Retomando a imagem inicial, observa-se que o fato de Lobato ter tirado a criança do colo colocando-a de pé no chão permitiu o estabelecimento de uma nova postura que pode ser apontada como a tendência mais importante da produção contemporânea de literatura infantil: adulto e criança podem

33 Idem, op. cit., p. 107 
colocar-se agora frente a frente, numa posição dialógica e, mantendo as especificidades de suas condições de maturidade e infância, podem compartilhar e descobrir diferentes formas de ver o mundo através da literatura.

O terceiro período da literatura infantil brasileira, de meados de 1980 a meados de 1990, é denominado por Gregorin Filho como período pós-lobato, por ser marcado pela forte influência das inovaçóes introduzidas por Lobato e pelo experimentalismo que se instaura, por causa disso, na produção de livros para crianças. Esse experimentalismo se firma a partir das influências da abertura política na concepção de educação, que abala e demanda reformas na Lei de Diretrizes e Bases da educação nacional de 1961, a partir das novas formulações da Pedagogia e da Psicologia com relação à infância. A literatura se mostra inquieta e questionadora abordando questóes cotidianas e mais realistas. Há uma busca pela aproximação com o leitor-criança através do aguçamento da curiosidade do leitor e do estabelecimento do dialogismo no texto. Além disso, o apelo à visualidade começa a impor sua força na determinação da especificidade da literatura infantil. É o momento em que a literatura para crianças e jovens "mostra um mundo em construção para uma criança que passa a ser vista como um ser em formação" "34, e não mais como um ser passivo e manipulável pela simples imposição de valores e ideias.

O último período, chamado de contemporâneo, que vai de meados de 1990 até a atualidade, é apontado como o momento em que se encontra consolidada uma produção literária para as crianças que não nasce para se tornar mero recurso pedagógico, mas cujas principais funçóes são o lúdico, o catártico e o libertador, além do cognitivo e do pragmático, já que visa a preparar o indivíduo para a vida num mundo repleto de diversidades. Os autores contemporâneos, ao menos a maioria deles,

trazem as vozes das crianças e o universo cotidiano com seus conflitos para serem lidos/vistos/sentidos na literatura infantil de hoje, conflitos esses levados às crianças com uma proposta de diálogo, não somente de imposição de valores, por meio de uma literatura que busca a arte, sua característica primeira. ${ }^{35}$

34 GREGORIN FILHO, op. cit., p. 32

35 Idem, op. cit., p.30 


\title{
Considerações finais
}

É possível afirmar que a gangorra do percurso histórico da literatura infantil alcançou certo equilíbrio, movendo-se o balanço do polo da pedagogia em direção ao polo da literatura, quando a palavra-arte se impôs como valor inerente à literatura infantil. Para alguns esse equilíbrio seria o ideal da literatura infantil, enquanto outros postulam que só haverá, de fato, uma literatura infantil quando todo e qualquer comprometimento com a pedagogia tenha sido superado. Talvez nunca se estabeleça uma fórmula ideal e definitiva para o que seja ou deva ser a literatura infantil, até porque as concepçôes de infância tendem a se modificar afetando a literatura voltada a ela.

Diante de todo o exposto, conclui-se que, de fato, qualquer consideraçáo teórica ou crítica sobre obras de literatura infantil deve considerar a identificação da concepção de infância presente nas obras analisadas como uma questão, senão fundamental, ao menos de grande relevância em suas formulaçóes sobre a literatura que se veste com uma roupa infantil.

\section{LETTERATURA PER BAMBINI: PRESSO L'INFANZIA, LA PEDAGOGIA E L'ARTE}

\begin{abstract}
SINTESI
Il presente testo vuole discutere due dei concetti fondamentali per la teoria e la critica dela letteratura per bambini: la nozione di infanzia sulla quale si scrivono libri per bambini e la funzione sociale che si aspetta di questa letteratura. Il testo analisa ancora come le diverse nozioni di infanza hanno determinato il percorso dela letteratura per bambini fatta in Brasile.
\end{abstract}

PAROLE CHIAVI: Letteratura per bambini; Teoria; Infanzia

Recebido em: 27/07/2012

Aprovado em: 05/02/2013 